\title{
Evaluating the Management Information System of Integrated Medical Emergency Care in Batang Regency, Indonesia
}

\author{
https://doi.org/10.3991/ijoe.v16i07.14725 \\ Wahyu Sulistiadi $\left.{ }^{\bowtie}\right)$, Siti Nurhidayah, Al Asyary \\ Universitas Indonesia, Depok, Indonesia \\ wahyuseui.ac.id
}

\begin{abstract}
An emergency can happen anywhere and anytime, especially in developing countries with a high potential for emergencies, such as Eastern European countries as well as Indonesia. This study aimed to find out the quality of PSC 119 Si Slamet as a prehospital emergency service innovation. The data collection in this study was carried out in a location, namely, Batang Regency, Indonesia, in May-June 2018. The qualitative data collection methods used in this study are in-depth interviews and document reviews. This study was using Service Quality (Servqual) questionnaire. The results show that PSC 119 Si Slamet provides easy access to emergency services to the community 24 hours a day and 7 days a week by simply calling 119 numbers, sending messages via SMS and WhatsApp, or using the Android-based application, with a maximum response time target of 10 minutes. Batang is one of the regencies (rural area) in Central Java province, located on the main coastline, with a hilly geographic condition with many derivatives, climbs, and sharp curves, which is one of the causes of the high number of traffic accidents in the area. This emergency care information systems, with Android-based application, was aimed at improving the quality of services in the health sector, especially emergency services. This service is of good quality as seen from the tangible, reliability, responsiveness, assurance, and empathy dimensions. However, in the implementation, the socialization aspect is not the best to some people. The recommendation given was the need to increase the PSC 119 socialization of Si Slamet not only regionally but also internationally to be massive, especially in developing countries.
\end{abstract}

Keywords-Medical emergency, health care information systems, rural health services, developing countries

\section{Introduction}

An emergency can happen anywhere and anytime and can befall a person or group of people [1]. Every day, around the world, people who are sick and injured seek treatment, especially in some countries with a high potential for emergencies [2,3], such as Indonesia [4]. In 2018, Indonesia experienced devastating natural disasters, such as the earthquake and tsunami that occurred in West Nusa Tenggara and Central Sulawesi, 
with a total of more than two thousand deaths and hundreds of thousands of injuries and displacement [5].

Indonesia has initiated an emergency system [6, 7], and this medical emergency care via 119 appeared with the benefit that it is available 24 hours a day and is free, making it easier for people to access emergency services [8]. This medical emergency service uses the Public Safety Center (PSC) 119 approach, which not only provides call center services but also provides emergency services directly to patients or victims [8].

Medical emergency services can be sourced from the government and/or CSR [911]. They can provide first aid in emergency cases and speed up patient handling time or response time [12]. Health-care providers receive child services and adults with medical, surgical, and obstetric emergencies, including injuries and infections, heart attacks and strokes, asthma, and acute complications of pregnancy [13]. Such conditions require appropriate immediate help in the form of first aid. The aid measures aim to save a patient's life, prevent and limit the occurrence of the disability, and alleviate suffering [14].

However, the implementation of this system is partial in some regions [15], and the fact that the community has difficulty obtaining emergency services when the emergency conditions are severe raises a question on the potential and service standards in becoming a national system in emergency response. Therefore, this study will examine the quality of the services of the Integrated Emergency Management System (SPGDT) PSC 119 "Si Slamet” in Batang Regency in 2018.

\section{Methods}

\subsection{Research design and detting}

The qualitative approach was carried out in a location, namely, Batang Regency's Health Office, in May-June 2018. This rural regency located in Jawa Tengah Province of Indonesia. The study was approved by the Ethical Committee of Faculty of Public Health, Universitas Indonesia No: 496 /UN2.F10/PPM.00.02/2018.

\subsection{Participants}

The characteristics of IDI informants are described in the following table 1: 
Table 1. Characteristic of IDI Informants

\begin{tabular}{|c|c|c|c|c|}
\hline No. & Informant & Gender & Age & Education \\
\hline 1 & $\begin{array}{l}\text { Representation of the Central Java Provincial Health } \\
\text { Office }\end{array}$ & M & 48 & Master's degree \\
\hline 2 & $\begin{array}{l}\text { Many representatives/staff from the Batang Police } \\
\text { Unit representative }\end{array}$ & $\mathrm{M}$ & 36 & Bachelor's degree \\
\hline 3 & $\begin{array}{l}\text { Regional Disaster Management Agency (BPBD) Re- } \\
\text { gency of Batang }\end{array}$ & $\mathrm{M}$ & 43 & Master's degree \\
\hline 4 & $\begin{array}{l}\text { Representative of the Fire Department of the Regency } \\
\text { of Batang }\end{array}$ & $\mathrm{M}$ & - & Bachelor's degree \\
\hline 5 & Representative of PMI Batang Regency & $\mathrm{M}$ & 31 & Diploma \\
\hline 6 & PSC representative 119 "Si Slamet" & $\mathrm{M}$ & 26 & High School \\
\hline 7 & PSC 119 health worker "Si Slamet" & $\mathrm{M}$ & 28 & Diploma \\
\hline 8 & $\begin{array}{l}\text { Community A who had made } 119 \text { PSC "Si Slamet" } \\
\text { calls }\end{array}$ & $\mathrm{M}$ & 23 & Diploma \\
\hline 9 & $\begin{array}{l}\text { Community B who had carried out } 119 \text { PSC "Si } \\
\text { Slamet" calls }\end{array}$ & $\mathrm{M}$ & 23 & Diploma \\
\hline 10 & $\begin{array}{l}\text { Community B who had carried out } 119 \text { PSC "Si } \\
\text { Slamet" calls }\end{array}$ & $\mathrm{M}$ & 24 & Diploma \\
\hline 11 & $\begin{array}{l}\text { Community C who had never made } 119 \text { PSC "Si } \\
\text { Slamet" calls }\end{array}$ & $\mathrm{F}$ & 26 & Bachelor's degree \\
\hline 12 & $\begin{array}{l}\text { People in D who had never made } 119 \text { PSC “Si } \\
\text { Slamet” calls }\end{array}$ & $\mathrm{F}$ & 22 & High school \\
\hline 13 & $\begin{array}{l}\text { People in D who had never made } 119 \text { PSC "Si } \\
\text { Slamet" calls }\end{array}$ & $\mathrm{F}$ & 24 & Diploma \\
\hline
\end{tabular}

\subsection{Instruments}

There are five dimensions of Service Quality (Servqual) theory as to indicate the quality of PSC 119 Si Slamet services in this study. These consisted of tangible, reliability, responsiveness, assurance, and empathy[16].

\subsection{Data collection}

The data collection in this study was carried out after passing through the ethical review of the Ethics Commission of the Public Health Faculty of Universitas Indonesia and being declared eligible to be carried out and obtaining research permission from the research location. The data used were obtained through in-depth interviews (IDI), while the secondary data were obtained through the collection of research-related documents. 


\section{Results}

\subsection{Tangible}

Aspects measured in the dimension of physical evidence of the quality of the SPGDT PSC 119 service are the physical things that can be felt directly from the service, including the facilities, equipment, and physical appearance of personnel. The facilities and equipment are adequate, and the appearance of attractive personnel provided by PSC 119 Si Slamet for emergency treatment is sufficient. This is described in the following interview results:

For the Slamet PSC, there are 4 posts, here as the Central post, Subah post, post Gringsing II and the post office there because of the accident-prone lane. The Slamet has an ambulance motorbike 1, an ambulance car, 21 ambulances scattered in each network health center, yesterday came 1 from the Ministry of Health emergency ambulance car and also had a car for promotion. Uniforms used when handling Since 2016 using BEMS uniforms currently wearing PSC 119 uniforms of Slamet . . (PS)

This was corroborated by the opinion of the public that when providing emergency services in terms of the facilities, equipment, and physical appearance of personnel, it was good enough. This is described in the following interview results:

When the Slamet officer arrived at the scene using an ambulance, the officer pulled an interesting suit wearing a uniform that read PSC $119 \ldots$. . MP1)

\subsection{Reliability}

The aspect measured in the dimensions of the reliability of the SPGDT PSC 119 service is its ability to provide immediate and reliable services according to the case. The ability of Si Slamet 119 PSC officers in providing appropriate emergency services are already standard. The clerk already has a certificate in emergency first aid (PPDG), and SOP procedures for Si Slamet's services were according to the case. This is described in the interview excerpts below:

The staff at the PSC are from the minimum standard of medical staff, nurses, provided that they are trained in PPGD . . . (DP)

\subsection{Responsiveness}

The aspects measured in the dimensions of responsiveness of the SPGDT PSC 119 service is its ability to assist service users and provide fast service. The SPGDT PSC 119 services have changed health services. Initially, patients visit health facilities in the event of an emergency, but now with the PSC 119 Si Slamet, if there is an emergency case, the patient easily seeks help by making phone calls to 119 numbers, sending messages via SMS and WhatsApp, or using the Si Slamet Android application so the officers will come to him/her. This speeds up the response time of the emergency department. This is described in the following interview results: 
Before the Slamet happened, surely the handling was slow, let alone the accident rate. Many of the problems, we were from the example, most of the victims happened because the first time was handling, the second was wrong in handling the place, so if before the Slamet, the accident victim died because if not When rescued, the second mistake of rescue was still unfamiliar if the people were not familiar with medical or rescue methods if it was related to the existence of Slamet so that time could be overcome at that time we set 10 minutes at the longest within 10 minutes if there were officers coming. The Slamet has 3 reports to call, application or WhatsApp, SMS will be the victim or patient who needs Slamet they will be able to use the telephone, call 11902851119 or use the application in the photo or use an SMS tweet by sending a bad send to Slamet or WhatsApp, Slamet's number is also made WhatsApp 082231 $119119 \ldots$. (AD).

The results of the document review conducted at the time of the study obtained data related to emergency response times carried out by Si Slamet 119 PSC from 2016 to May 2017 and from 2017 to May 2018. The researcher got the difference between the response time of 2017 and the response time of 2018 using dependent T-test. The reason for using T-test is because the data obtained are numerical, normal data distribution, and both groups can be paired.

The response time set by the Si Slamet 119 PSC is a maximum of 10 minutes. The response time for the $2017 \mathrm{~T}$-test was taken in as many as 33 cases with a response time of $<10$ minutes, while the response time of the T-test in 2018 was taken in as many as 33 cases with a response time of $>10$ minutes. Based on the T-test, the following results were obtained:

Table 2. Effect of Si Slamet 119 PSC Service Innovation on the Emergency Response Time in Batang Regency

\begin{tabular}{|l|c|c|c|c|c|}
\hline Time response & $\mathbf{N}$ & Mean & $\begin{array}{c}\text { Elementary } \\
\text { school }\end{array}$ & SE & P-Value \\
\hline Year 2017 & 33 & 4.7 & 2.5 & 0.4 & \multirow{2}{*}{0,0005} \\
\hline Year 2018 & 33 & 15.7 & 6.6 & 1.1 & \\
\hline
\end{tabular}

Based on Table 2, it can be seen that the Si Slamet 119 PSC service innovation increased the emergency response time by 11 minutes, from 4 minutes 7 seconds in 2017 to 15 minutes in 2018 . T-test results obtained $p$-value $=0.0005$, which means that there is a significant difference in the emergency response time between 2017 and 2018.

The PSC implementation process 119 of Si Slamet in Batang Regency still had problems, one of which was from the community because there were still some people who did not know about the existence of the Si Slamet because of the lack of introduction in the community. This is described in the following interview results:

There are not many people, especially the southern trunk, who know the PSC $119 \mathrm{Si}$ Slamet... (AD)

Still lacking knowledge about the community regarding the application . . . (MP1)

Who is Slamet? Ooo doesn't know... (MB3) 


\subsection{Assurance}

Aspects measured in the dimension of quality assurance of the SPGDT PSC 119 services are knowledge and respect, courtesy of service providers, and their ability to grow trust by service users and confidence.

In providing emergency services, SPGDT PSC 119 seeks to gain public trust by keeping the reporter's data confidential and responding to calls quickly. This is described in the following interview results:

There if there is an accident, it is usual to directly call 119 the Slamet, because there was a time when the accident happened to be called, the response was fast so people here call the Slamet if there is an accident ... (MP2)

\subsection{Empathy}

The aspect measured in the dimension of empathy of the SPGDT PSC 119 services is the attention given by the officers in health services to the users in person. In providing emergency services, SPGDT PSC 119 officers work wholeheartedly according to the needs of the community related to the emergency treatment. This is described in the following interview results:

We still have a lot of patience. Because when we need data or check history, it's not all in the community, it understands what data we need. So we have to be smart, ask him. Yes, you know, sis, sometimes, for example, the family is panicking. So when they were asked, they were confused... (PS)

\section{Discussion}

\subsection{Tangible}

The PSC 119 services in Batang have facilities and equipment adequate to serve emergencies. The PSC 119 personnel are provided work uniforms to ensure concise and conspicuous attention to emergency care. Si Slamet PSC currently also has four posts located in hazardous paths prone to accident, namely, the central command post located in the Batang Regency Health Office, the subah post located in the Subah Health Center, the Gringsing II post located at Gringsing II Health Center, and the writing post located at Tulis Health Center. Moreover, Si Slamet has a one ambulance motorbike, 22 ambulance vehicles scattered in each network health center, and one car for promotion. There are uniforms used when handling. Since 2016, those using BEMS uniforms have been wearing the PSC 119 Si Slamet uniform.

Tangibles (physical evidence) include the appearance of facilities, equipment, and appearance of officers [16]. Services have an intangible nature, which has an impact on the difficulty of potential service users in evaluating a service before the service is used and in time will lead to a perception of the risk of increased purchases [17]. Therefore, in evaluating a service, customers often rely on real cues or physical evidence of a service before buying it and assess its satisfaction during and after consumption. 
Services offered by companies are essentially wrapped or packaged in the company's physical facilities, and an external image is communicated about what is in it to service users.

\subsection{Reliability}

The ability of the PSC 119 officer to provide emergency services was in accordance with the standards, and the SOP procedures for Si Slamet's services were in accordance with the case. The PGDT PSC 119 Si Slamet officer has a minimum number of medical nurses with the condition that he has been trained in PPGD emergencies. The SPGDT PSC 119 nurse also serves as an ambulance driver with the requirement to have an A SIM and pass a safety drive test conducted by the Batang Regency Police Unit.

The accuracy of services related to the medical aspect is very important as it affects the lives of patients [18]. Patients certainly do not want any life-threatening errors. In terms of nonmedical, the patient also wants something that is accurate for him. Thus, providing accurate health services is required not only in terms of the medical aspect but also in terms of the nonmedical. When a service can provide accuracy both in terms of the medical and nonmedical aspect, of course, patients will feel happy with the services provided [19].

\subsection{Responsiveness}

SPGDT PSC 119 services has changed health services in that initially, patients visit health facilities in the event of an emergency, but now with the PSC 119 Si Slamet, if there is an emergency, the patient can easily seek help by making phone calls to 119 numbers, sending message via SMS or WhatsApp, or using the Si Slamet Android applications so the officers come to the patient. This speeds up the response time of the emergency department. Death of victims of an emergency disaster can occur because of the slow handling and wrong handling at the scene. The existence of Si Slamet, which provides three types of reporting (telephone, application, or WhatsApp and SMS) and has the principle of emergency treatment time for a maximum of 10 minutes, can reduce mortality and disability caused by emergency cases.

Responsiveness is the willingness of service providers to help customers and provide timely services [16]. In health care, responsiveness is part of the interpersonal relationship between the health-care provider and patient. One strategy in improving customer satisfaction is to always help deal with patient problems [20]. Another form of responsiveness that can create satisfaction for patients is to provide timely services.

The PSC 119 Si Slamet implementation in Batang Regency is quick when viewed from the readiness of the officers, and the services provided is considered to be on time. Responsive response from officers helps reduce mortality and disability rates because of the right and prompt help.

However, the responsiveness of the officer has not been realized by some people who do not know about Si Slamet. This program is still lacking in socialization to the community in one subregency. Further effort is needed in evaluating how socialization can work. One way of delivering socialization must be to know things such as ethnic 
diversity and the characteristics of the people who live in the place so that the delivery becomes more effective. With the emergence of new awareness from the public, emergency rates will of course decline in the region.

\subsection{Assurance}

The ability of health-care providers to build trust in patients is very important. The trust of patients to health-care providers can be formed through information delivered to patients. In providing emergency services, SPGDT PSC 119 seeks to gain the trust of the public by keeping the reporter's data confidential and responding to the call quickly.

The way officers communicate to customers creates a good impression, so it is very important for service providers to consider this [21]. Patients do not have enough knowledge to assess the technical capacities of health services [22]. Therefore, patients tend to assess health services through their impression of professionalism from healthcare providers, for example, through the information provided by doctors regarding the explanation of a patient's illness, how long should the patient be treated with his illness, etc. The ability of health-care providers to build the patient's trust is not only formed through information delivered from the medical personnel but also from the nonmedical officer. Clarity of information from nonmedical officers also has a major influence on patient satisfaction.

Based on the results of the research and the above theory, it can be seen that the ability of health-care providers to gain the trust of patients affects patient satisfaction. This trust can be reflected in several things, namely, the knowledge of officers (both medical and nonmedical officers should provide clear information to patients), their courtesy, and their ability to provide security to patients.

\subsection{Empathy}

Empathy means trying to be in someone else's position and understanding his condition [23]. The aspect of empathy takes an important role in the implementation of PSC 119 in Batang Regency where the attention given by officers in health services to patients feels deeper and meaningful. Officers are more familiar, caring, and comfortable in treating patients and are quick and responsive when taking action.

SPGDT PSC 119 officers provide emergency services in the service of the ministry with all their heart to serve the needs of the community related to emergency care. Emergency patients indeed require special attention depending on the case, so it will more and intentions expressed willingness to officers of the PSC 119 Si Slamet. If this is not followed up by the officer, it will have a negative impact on the patient. Empathy is important [24]. The attitude and sincerity of the officers is a priority that must be corrected because the assessment is not good for the patients themselves [25]. 


\subsection{Limitations}

Service quality is more difficult to measure than measuring a product because the product is shaped and colored while the quality is formless and colorless [26]. The qualitative data that gathered in this study was limited by the characteristics of the informants. These included of length of working history, the relevancy with previous educational background as well as their competency status. However, this study measures how quality of the PSC SPGDT Service Unit 119 Si Slamet Batang Regency Health Office as the system is provided through the perspective of the service provider.

\section{Conclusion}

This program changes the pattern of health services to being proactive, especially in terms of emergency. Several stakeholders, including firefighters, the Indonesian Cross Red, police, BPBD, health universities, corporations, the Indonesian Health Insurance Committee (BPJS), and hospitals, should be connected with this system. This organization is a primary referral service and is still under the health service. The increasing number of officers, the number of ambulance vehicles, and the naming and launch of the new version of the application "Si Slamet," with the PSC Slamet renamed, are essential for further development. The promotion of this emergency system service is required, as not only the people of Batang Regency and Pantura territories can use it, but also it has the potential to be applied massively throughout Indonesia and other developing countries.

\section{Acknowledgement}

This study was supported by Sub-Directorate of Research Plan and Development, the Directorate for Research and Community Engagement, Universitas Indonesia (DRPM-UI). We thank to several parties which consisted of: Universitas Indonesia and the Batang Regency Local Government

\section{$7 \quad$ References}

[1] Salama P, Spiegel P, Talley L, et al. Lessons learned from complex emergencies over past decade. Lancet 2004; 364: 1801-1813. https://doi.org/10.1016/s0140-6736(04)17405-9

[2] Giorgetti C. A principled approach to state failure: international community actions in emergency situations. Leiden, The Netherlands: Brill, 2010. https://doi.org/10.1163/ej. 9789004181274.i-198

[3] Butt S, Nasu H, Nottage L. Asia-Pacific disaster management. Springer, 2016.

[4] Qiantori A, Sutiono AB, Hariyanto H, et al. An emergency medical communications system by low altitude platform at the early stages of a natural disaster in Indonesia. J Med Syst 2012; 36: 41-52. https://doi.org/10.1007/s10916-010-9444-9 
[5] Sangkala MS, Gerdtz MF. Disaster preparedness and learning needs among community health nurse coordinators in South Sulawesi Indonesia. Australas Emerg Care 2018; 21: 2330. https://doi.org/10.1016/j.auec.2017.11.002

[6] Indonesian Ministry of Health. Peraturan Menteri Kesehatan Republik Indonesia Nomor 19 Tahun 2016 tentang Sistem Penanggulangan Gawat Darurat Terpadu.

[7] Risald R, Suyoto S, Santoso AJ. Mobile application design emergency medical call for the deaf using UCD method. Int J Interact Mob Technol 2018; 12: 168-177. https://doi.org/10.3991/ijim.v12i3.8754

[8] The Governor of Central Java Province. Peraturan Gubernur Jawa Tengah No. 15 tahun 2017 Tentang Sistem Penanggulangan Gawat Darurat Terpadu (SPGDT) Di Provinsi Jawa Tengah. https://doi.org/10.36762/litbangjateng.v17i1.759

[9] Shastry S, Koenig KL, Hirshon JM. Zika virus: critical information for emergency providers. Emerg Med Clin 2016; 34: e25-e37. https://doi.org/10.1016/j.emc.2016.04.001

[10] Faul M, Dailey MW, Sugerman DE, et al. Disparity in naloxone administration by emergency medical service providers and the burden of drug overdose in US rural communities. Am $J$ Public Health 2015; 105: e26-e32. https://doi.org/10.21 05/ajph.2014.302520

[11] Nable J V, Tupe CL, Gehle BD, et al. In-flight medical emergencies during commercial travel. N Engl J Med 2015; 373: 939-945. https://doi.org/10.1056/nejmra1409213

[12] Brady PW, Zix J, Brilli R, et al. Developing and evaluating the success of a family activated medical emergency team: a quality improvement report. BMJ Qual Saf 2015; 24: 203-211. https://doi.org/10.1136/bmjqs-2014-003001

[13] Indonesian Ministry of Health. Seri PPGD, Penanggulangan penderita gawat darurat/general emergency life support (GELS): sistem penanggulangan gawat darurat terpadu (SPGDT). Cetakan ketiga. https://doi.org/10.33560/jmiki.v7i1.218

[14] Purwadianto A, Sampurna B. Kedaruratan Medik. Tangerang Selatan, Indonesia: Binarupa Aksara, 2013.

[15] Obermeyer Z, Abujaber S, Makar M, et al. Emergency care in 59 low-and middle-income countries: a systematic review. Bull World Health Organ 2015; 93: 577-586. https://doi.org/10.2471/blt.14.148338

[16] Zeithaml VA, Parasuraman A, Berry LL. Delivering quality service: Balancing customer perceptions and expectations. New York: Simon and Schuster, 1990.

[17] Tjiptono F. Service Marketing Esensi dan Aplikasi. Jogjakarta: Marknesis, 2009.

[18] Al-Dalahmeh M, Al-Shamaileh O, Aloudat A, et al. The Viability of Mobile Services (SMS and Cell Broadcast) in Emergency Management Solutions: An Exploratory Study. Int J Interact Mob Technol 2018; 12: 95-115. https://doi.org/10.3991/ijim.v12i1.7677

[19] Lumenta B. Pelayanan medis: citra, konflik dan harapan. Jakarta: Kanisius, 1989.

[20] Bramson R. Customer Loyalty: 50 Strategi Ampuh Membangun dan Mempertahankan Loyalitas Pelanggan. Jakarta: Prestasi Pustaka, 2005.

[21] Vermeir P, Vandijck D, Degroote $S$, et al. Communication in healthcare: a narrative review of the literature and practical recommendations. Int J Clin Pract 2015; 69: 1257-1267. https://doi.org/10.1111/ijcp.12686

[22] Shippee ND, Domecq Garces JP, Prutsky Lopez GJ, et al. Patient and service user engagement in research: a systematic review and synthesized framework. Heal Expect 2015; 18: 1151-1166. https://doi.org/10.1111/hex.12090

[23] Patton N, Newton B. Developing capability for emphatic practice. In: Developing Practice Capability: Transforming Workplace Learning. Leiden, The Netherlands: BRILL, 2018, p. 183. https://doi.org/10.1163/9789004366923_015 
[24] Ge L, Wang Q, Hu P, et al. Method of Wireless Sensor Network Node Deployment for the Emergency Environment. Int $J$ Online Biomed Eng 2017; 13: 163-173. https://doi.org/10.3991/ijoe.v13i08.7422

[25] Loi UR, Gemzell-Danielsson K, Faxelid E, et al. Health care providers' perceptions of and attitudes towards induced abortions in sub-Saharan Africa and Southeast Asia: a systematic literature review of qualitative and quantitative data. BMC Public Health 2015; 15: 139. https://doi.org/10.1186/s12889-015-1502-2

[26] Szwamel K, Kurpas D. Analysis of the structure of medical services branch of the Hospital Emergency Ward with special reference to the benefits provided to patient with minor injuries. Fam Med \&amp; Prim Care Rev 2015; 17: 124-130.

\section{Authors}

Wahyu Sulistiadi is currently an Associate Professor at Health Administration and Policy Department, Faculty of Public Health, Universitas Indonesia. He is also assigned as Dean at Faculty of Public Health, Pembangunan Nasional "Veteran" University (Indonesia), and Director at Center for Educational and Community Services (P3M-FKM), Universitas Indonesia (Indonesia).

Siti Nurhidayah is a researcher in the Center for Educational and Community Services (P3M-FKM), Universitas Indonesia (Indonesia).

Al Asyary is an Indonesian public health informatics scientist, health information system educator, and Assistant Professor at Public Health Faculty of Universitas Indonesia, C Building 2nd Floor, Campus FKM-UI, in Depok, 16424, Indonesia. He formerly worked as Head of Public Health Science Postgraduate Program at the University of Muhammadiyah Prof Dr. HAMKA (Indonesia).

Article submitted 2020-03-08. Resubmitted 2020-04-23. Final acceptance 2020-04-24. Final version published as submitted by the authors. 